N. A. Korshunova, R. F. Tukhvatullina, O. S. El'tsov LTD «STC-Immuno Analisys» Blukhera st., 43, Ekaterinburg, 620137, Russia E-mail: o.s.eltsov@urfu.ru

\title{
The study of the curing of the polyurethane coating by method of IR spectroscopy
}

The results of the study of the curing process of polyurethane compositions with participation of two different catalysts by the method of IR spectroscopy are given. The time dependences of curing of polyurethane coatings from concentrations of catalysts were determined, on the basis of which the most effective catalyst was selected.

Key words: polyurethane, polyol, isocyanate, chemical curing, IR spectroscopy.

Received: 04.10.2016; accepted: 11.10.2016; published: 30.12.2016.

$$
\begin{array}{r}
\text { Н. А. Коршунова, Р. Ф. Тухватулина, О. С. Ельцов } \\
\text { ООО «ИТП Иммуноанализ» } \\
620137, \text { ул. Блюхера, 43, Екатеринбург, Россия } \\
\text { E-mail: o.s.eltsov@urfu.ru }
\end{array}
$$

\section{Изучение отверждения полиуретановых покрытий методом ИК-спектроскопии}

Приведены результаты исследования процесса отверждения полиуретановых композиций с участием двух различных катализаторов методом ИК-спектроскопии. Определены временные зависимости отверждения полиуретанового покрытия от концентраций катализаторов, по которым выбран наиболее эффективный катализатор.

Ключевые слова: полиуретан; полиол; изоционат; химическое отверждение; ИК-спектроскопия.

Поступило: 04.10.2016; принято: 11.10.2016; опубликовано: 30.12.2016.

(c) Korshunova N. A., Tukhvatullina R. F., El'tsov 0. S., 2016

One of the most common plastic materials today is polyurethane. The widespread use of this polymer is due to the wide scope and high rates of physicalmechanical properties as strength, wear resistance, resistance to swelling in vari- ous oils and solvents and ozone- and radiation resistance and others $[1,2]$.

The combination of high elasticity with wide range of hardness defines the excellent operational properties of the products based on them. The polymer is 
able to withstand heavy loads, less subject to aging than other substances. It is resistant to temperature extremes, sunlight, salts, solvents on organic base.

Therefore, the establishment of the protective anti-corrosion polyurethane coatings, used in large industrial objects (bridges, overpasses, etc.) is an actual task today.

The obtaining of the polyurethane occurs by the reaction of di- and polyfunctional isocyanates with di- and polyfunctional alcohols: rethane, which is difficult to implement in a coating outdoor environments [3-5]. In this case it seems more profitable variant of use of a catalyst which initially is added to the reaction mixture, accelerating the process of chemical curing of the coating. One of the most common catalytic systems is the combination of organometallic compounds and tertiary amines. Often this combination is due to the synergistic effect of these compounds.

The purpose of work is the determination of the influence of the concentration

$\mathrm{O}=-\mathrm{N}-\mathrm{R}^{-} \mathrm{N}=-\mathrm{O}+\mathrm{HO}-\mathrm{R}^{-2} \mathrm{OH}+\mathrm{O}=-\mathrm{N}-\mathrm{R}^{-1} \mathrm{~N}=-\mathrm{O}^{+} \mathrm{HO}-\mathrm{R}^{-}-\mathrm{OH}^{+}$

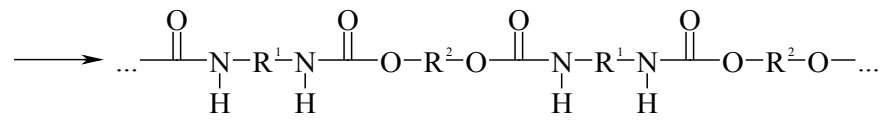

Since the curing time of the composition is sufficiently large, there is a need for its acceleration, while maintaining the properties of the very protective coating. In many experiments thermal processing is used for acceleration of curing of polyu-

\section{Materials and methods of study}

Spectra of prepared samples were recorded on a IR-Fourier spectrometer Bruker Alpha prefix diffusive reflection.

As starting components for the preparation of the samples were taken:*

Aliphatic polyisocyanate on the basis of isocyanurate hexamethylenediisocyanate (Desmodur N3390 of firm Bayer) $90 \%$ Solution in $n$-butyl acetate with a mass content of isocyanate groups of $19.6 \%$ was represented in the sale:

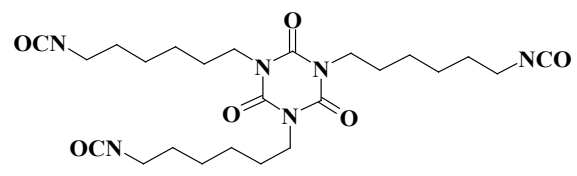

of tertiary amine as a catalyst on the rate of binding process of the components in the reaction for producing the polyurethane at room temperature by the method of IR spectroscopy.

the hydroxyl-bearing polyacrylate (Setalux DA 160X) with a mass content of hydroxyl groups of $1.6 \%$ in the sale form. Represented as $60 \%$ solution in xylene:

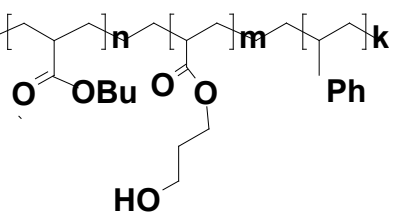

As organometallic catalyst was used $1 \%$ solution of dilaurate dibutylamine in butyl acetate, the tertiary amines are variable amounts of triethanolamine and diazobicycloundezen. 


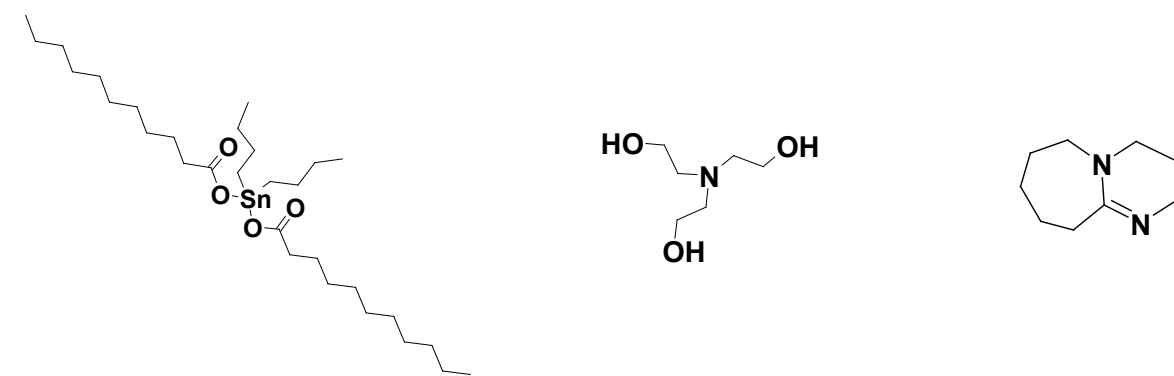

\section{The experimental part}

In advance 12 metal dies of a given size of $25.5 \times 4,5 \times 6,0 \mathrm{~mm}$ had been prepared. The sizes of dies were determined by measuring of the geometric parameters of the set of elements of the sample preparation for the recording of spectra of diffuse reflection. Metal dies on one side were mirror polished. Half the polished side was covered with the prepared sample using a special device enabling the thickness of the polyurethane coatings of 0.01-0.03 $\mathrm{mm}$, the other half surface was used as a standard of comparison.

The ratio was calculated by the following formula (calculated to anhydrous polyol):

$$
\frac{\mathrm{P}_{\mathrm{B}}}{\mathrm{P}_{\mathrm{A}}}=\frac{\mathrm{M}_{1} \cdot \mathrm{b}}{\mathrm{M}_{3} \cdot \mathrm{c}}
$$

where $\mathrm{P}_{\mathrm{A}}$ is the number of polyol, $\mathrm{g}$; $\mathrm{P}_{\mathrm{B}}$ is the number of isocyanate derivatives, $\mathrm{g} ; \mathrm{M}_{1}$ is the molecular weight of isocyanate groups 42.e.m.; $\mathrm{M}_{3}$ is the molecular weight of the hydroxyl groups 17.e.m.; $\mathrm{b}$ is the content of hydroxyl groups in the polyol, 1,6\%; c is the content of isocyano groups in the isocyanate, $19,6 \%$.

The founding ratio of isocyanate derivatives was to poliol by mass is $30,63: 100$. Given the content of solvents the mass ratio used 20,47:100.

The experiment was conducted in 4 parallel: without catalyst of tertiary amine, with content of catalyst of tertiary amine, $0.50 \%, 0.75 \%, 1.00 \%$ of the mass of the mixture. Isocyanate and polyol were mixed in a specific ratio, were added $1 \%$ by mass of the mixture dilaurate dibutylamine $1 \%$ solution in butyl acetate and the variable number of catalyst of tertiary amine was poured. So 4 parallels were got, where as the catalyst there was used triethanolamine, and 4 parallels, where the catalyst was diazobicycloundecen. The reaction mixture was prepared by stirring for 10 minutes at room temperature.

IR spectra were recorded with the frequency of once per day for 25 days. Additional treatment except correction of base line was not carried out.

\section{Results and discussion}

The assessment of chemical bonding of the components was based on changes in the concentration of isocyanate, which is determined by the intensity of the absorption band of the isocyanate group at $2291 \mathrm{~cm}^{-1}$ [6]. The process of formation of polyurethane was considered complete when the absorption band is not visible in the spectrum (Fig. 1). In Fig. 2 and 3 show graphs of the content of the absorption band of NCO-groups in time are shown.

As can be seen in the graphs, the speed of curing increases with increasing concentration of catalyst. Isocyanate groups 


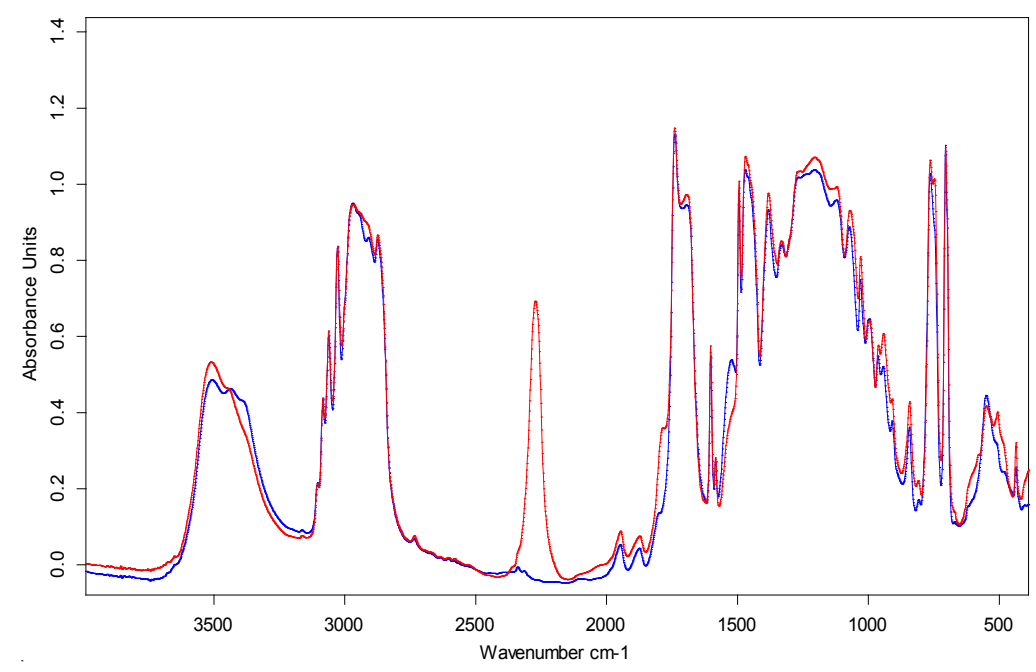

Fig. 1. Comparison of the IR spectra of the sample containing no triethanolamine at the beginning and end of the experience

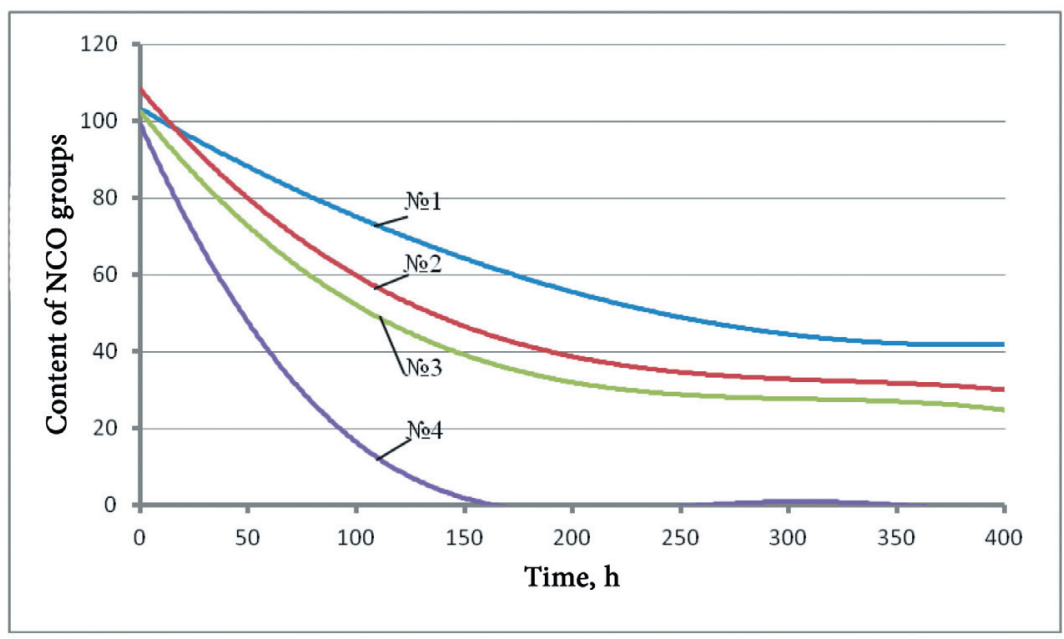

Fig. 2. Dependence of the intensity of the absorption bands from the time in the sample containing various concentrations of triethanolamine:

№ $1-0 \%$; № $2-0,5$ \%; № $3-0,75 \%$; № $4-1 \%$

are extremely reactive and rapidly interact with substances that contain hydroxyl and amino groups. This interaction of isocyanate groups and hydroxyl or amino groups of agents of chain growth leads to the formation of a larger number of urethane linkages. Therefore, the time for chemical curing of the reaction mixture of the polymer requires less at higher content of the catalyst. It should be noted that the physical curing is observed within hours after applying of the sample, whereas chemical curing was leaking much longer. Physical curing was evaluated by leaving of the nail strip on the sample of polyurethane 


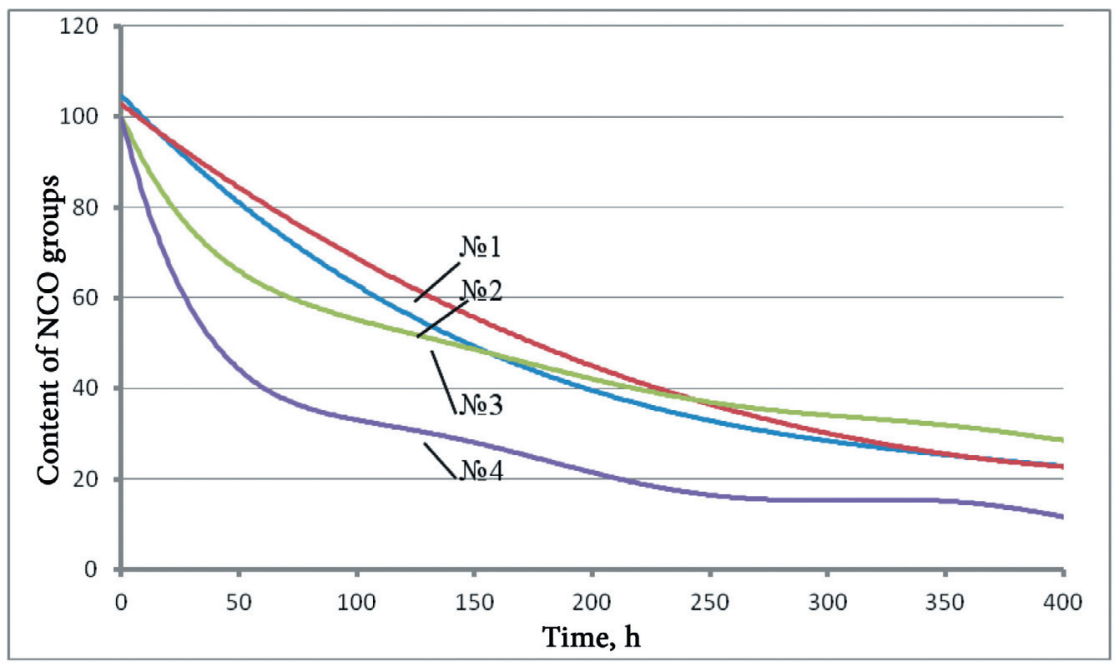

Fig. 3. Dependence of intensity of absorption bands from time in the sample containing different concentrations of diazobicycloundecen: № $1-0 \%$; № 2 - 0,5 \%; № 3 - 0,75 \%; № $4-1 \%$

In the resulting study the chemical curing of the polymer composition was observed faster when used as a catalyst triethanolamine. It should be noted also that the triethanolamine is cheaper than diazobicycloundecen, which explains its wide spread in industrial production.

The obtained experimental data can be used to optimize the technology of applying of polyurethane protective coatings and will predict the time to complete bonding of the components of the reaction mixture to achieve optimal physical-mechanical indicators.

* The authors thank the Head of R@D Division Prof. Kozhevnikov D. N of JSC SIH VMP for scientific and innovative work. for the objects of study and their interest in scientific research activity of students, hit UrFU.

\section{In Russian}

Одним из самых распространенных полимерных материалов современности является полиуретан. Широкое применение данного полимера обусловлено широкой областью применения и высокими показателями таких физико-механических свойств как прочность, износостойкость, устойчивость к набуханию в различных маслах и растворителях, а также озоно- и радиационностойкость и другие $[1,2]$.

Сочетание высокой эластичности с широким диапазоном твердости опре- деляет превосходные эксплуатационные свойства изделий на их основе. Полимер способен выдерживать большие нагрузки, меньше подвергается старению, чем другие вещества. Он устойчив к температурным перепадам, солнечным лучам, соли, растворителям на органической основе.

Поэтому создание защитных антикоррозионных полиуретановых покрытий, используемых в крупногабаритных промышленных объектах 
(мосты, эстакады и т. д.) является актуальной задачей на сегодняшний день.

Получение полиуретана происходит по реакции ди- и полифункциональных изоцианатов с ди- и полифункциональными спиртами:

Поскольку время отверждения композиции достаточно большое, возникла необходимость его ускорения при сохранении свойств самого защит- использования катализатора, который изначально добавляется в реакционную смесь, ускоряя процесс химического отверждения покрытия. Одной из распространенных каталитических систем является сочетание органометаллических соединений с третичными аминами. Причем зачастую такая комбинация обусловлена синергетическим эффектом этих соединений.

$$
\mathrm{O}=-\mathrm{N}^{-} \mathrm{R}^{-} \mathrm{N}=-\mathrm{O}+\mathrm{HO}-\mathrm{R}^{-2} \mathrm{OH}+\mathrm{O}=-\mathrm{N}^{-} \mathrm{R}^{-}-\mathrm{N}=-\mathrm{O}^{+} \mathrm{HO}^{-} \mathrm{R}^{-2} \mathrm{OH}^{+} \ldots \longrightarrow
$$

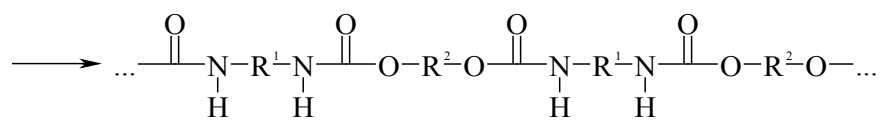

ного покрытия. Во многих опытах для ускорения отверждения полиуретана используется термическая обработка, которую трудно осуществить в условиях нанесения покрытий вне помещений [3-5]. В данном случае представляется более выгодным вариант
Цель работы: определение влияния концентрации третичного амина как катализатора на скорость процесса связывания компонентов в реакции получения полиуретана при комнатной температуре методом ИК-спектроскопии.

\section{Материал и методы исследования}

Спектры подготовленных образцов были записаны на ИК-Фурье спектрометре Bruker Alpha, приставка диффузионного отражения.

В качестве исходных компонентов для подготовки образцов были взяты*:

- алифатический полиизоционат на основе изоцианурата гексаметилендиизоционата (Desmodur N3390 компании Bayer). В продаже представлен как 90 \% раствор в н-бутилацетате с массовым содержанием изоционатных групп 19,6\%:

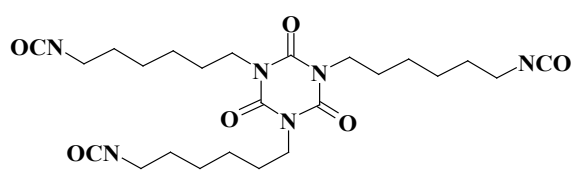

- гидроксилсодержащий полиакрилат (Setalux DA 160X) с массовым содержанием в продажной форме гидроксильных групп 1,6 \%. В продаже представлен как 60 \% раствор в ксилоле:

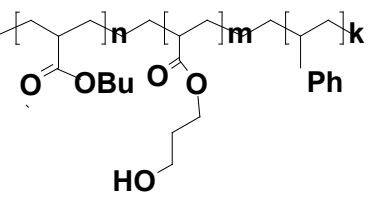

- в качестве органометаллического катализатора был использован 1 \% раствор дилаурат дибутилолова в бутилацетате, третичные амины - варьируемые количества триэтаноламина и диазобициклоундецена: 


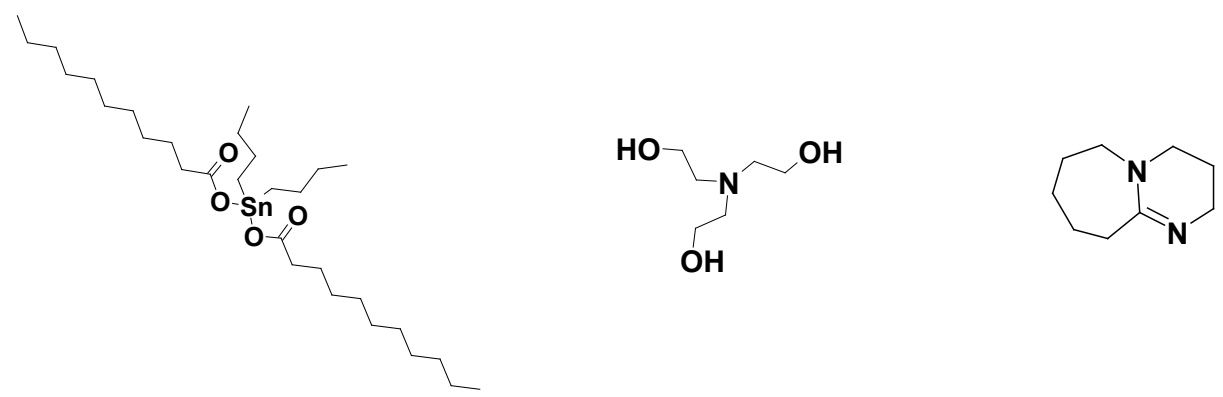

\section{Экспериментальная часть}

Предварительно были подготовлены 12 металлических плашек заданного размера $25,5 \times 4,5 \times 6,0$ мм. Размеры плашек были определены путем измерения геометрических параметров набора элементов пробоподготовки для записи спектров диффузного отражения. Металлические плашки с одной стороны были зеркально отполированы. Половина полированной стороны была покрыта подготовленным образцом с помощью специального устройства, обеспечивающего толщину полиуретанового покрытия 0,01-0,03 мм, другая половина поверхности использовалась в качестве эталона сравнения.

Соотношение компонентов рассчитывали по следующей формуле (в пересчете для безводного полиола):

$$
\frac{\mathrm{P}_{\mathrm{b}}}{\mathrm{P}_{\mathrm{A}}}=\frac{\mathrm{M}_{1} \cdot \sigma}{\mathrm{M}_{3} \cdot \mathrm{c}}
$$

где $\mathrm{P}_{\mathrm{A}}$ - количество полиола, г; $\mathrm{P}_{\mathrm{b}}$ - количество изоционата, г; $\mathrm{M}_{1}$ - молекулярная масса изоционатных групп, 42 а.е.м.; $M_{3}$ - молекулярная масса гидроксильных групп, 17 а.е.м.; 6 - содержание гидроксильных групп в полио- ле, 1,6 \%; с - содержание изоционатных групп в изоционате, 19,6\%.

Найденное соотношение изоционата к полиолу по массе составляет 30,63:100. Учитывая содержание растворителей, использовали массовое соотношение 20,47:100.

Эксперимент проводился в четырех параллелях: без катализатора третичного амина, с содержанием катализатора третичного амина 0,50 \%, 0,75\%, $1,00 \%$ от массы смеси. Смешивали в определенном соотношении изоционат и полиол, добавляли 1 \% от массы смеси дилаурата дибутилолова $1 \%$ раствор в бутилацетате и приливали варьируемое количество катализатора третичного амина. Таким образом получили четыре параллели, где в качестве катализатора использовали триэтаноламин, и четыре параллели, где катализатор диазобициклоундецен. Реакционную смесь готовили перемешиванием в течение 10 минут при комнатной температуре.

ИК-спектры записывались с периодичностью раз в сутки в течение 25 дней. Дополнительной обработки, кроме коррекции базовой линии, не проводилось. 


\section{Результаты и обсуждение}

Оценка химического связывания компонентов проводилась на основании изменения концентрации изоцианата, которая определялась по интенсивности полосы поглощения изоцианатной группы при $2291 \mathrm{~cm}^{-1}$ [6]. Процесс образования полиуретана считался законченным, когда данная полоса поглощения не просматривалась на спектре (рис. 1). На рис. 2, 3 представлены графики изменения содержания полосы поглощения NCOгруппы во времени.

Как видно на графиках, скорость химического отверждения увеличивается при повышении концентрации

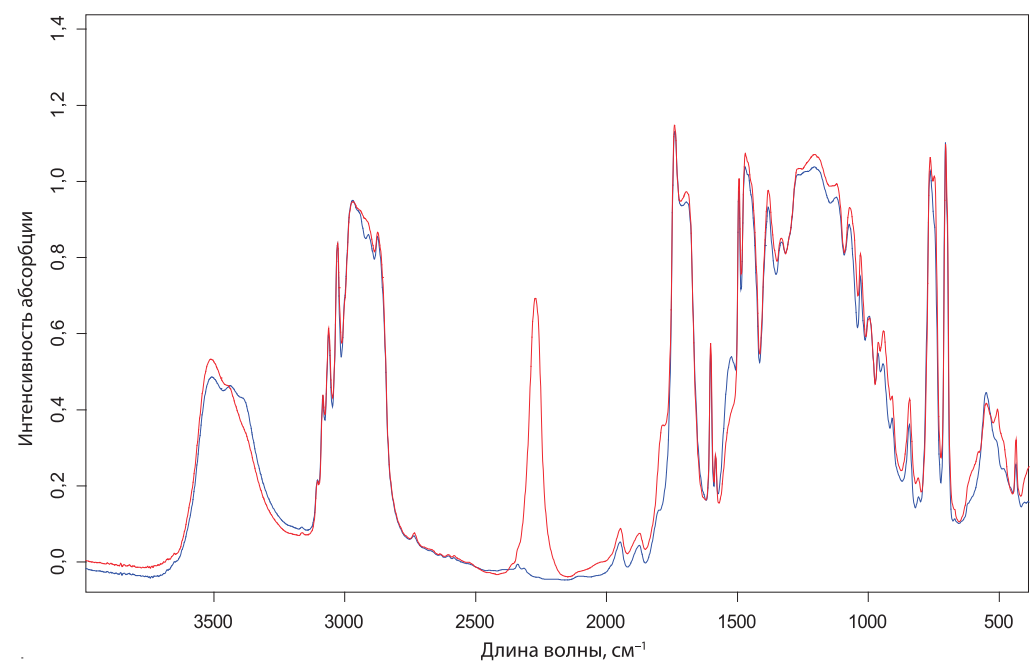

Рис. 1. Сравнение ИК-спектров образца, не содержащий триэтаноламин, в начале и в конце опыта

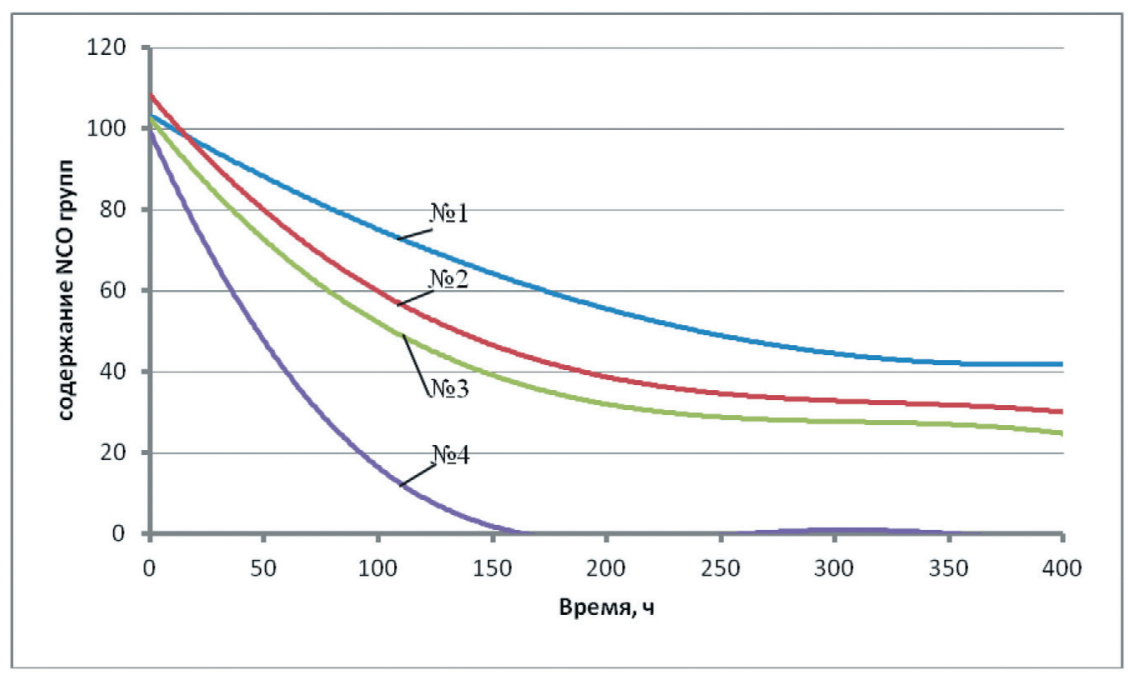

Рис. 2. Зависимость интенсивности полосы поглощения от времени в образце, содержащем различные концентрации триэтаноламина:

№ $1-0 \%$; № 2 - 0,5 \%; № 3 - 0,75 \%; № $4-1 \%$ 


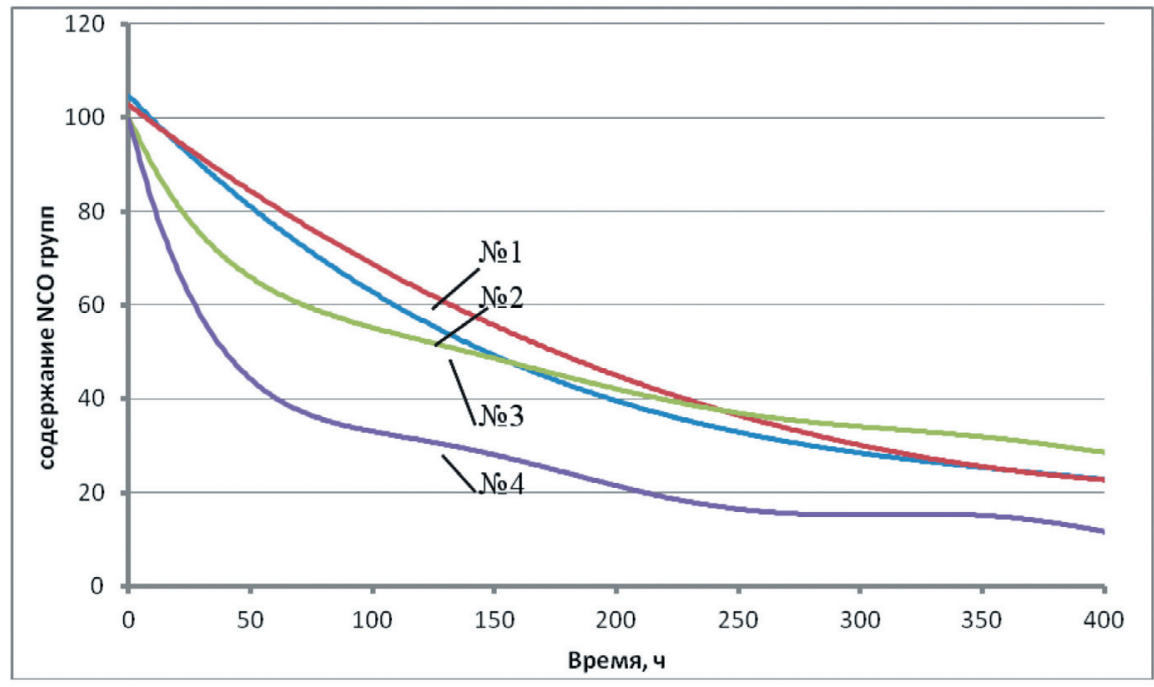

Рис. 3. Зависимость интенсивности полосы поглощения от времени в образце, содержащем различные концентрации диазобициклоундецена:

№ $1-0 \%$; № $2-0,5 \%$; № 3 - 0,75 \%; № 4 - $1 \%$

катализатора. Изоцианатные группы крайне реакционноспособны и быстро взаимодействуют с веществами, которые содержат гидроксильные и аминогруппы. Это взаимодействие изоцианатных групп и гидроксильных или аминогрупп агентов роста цепи приводит к образованию большего числа уретановых связей. Следовательно, время на химическое отверждение реакционной смеси полимера требуется меньше при большем содержании соответствующего катализатора. Стоит отметить, что физическое отверждение наблюдается через сутки после нанесения образца, тогда как химическое протекало намного дольше. Физическое отверждение оценивали по оставляемой ногтем полосе на образце полиуретана.

В полученном исследовании химическое отверждение полимерной композиции наблюдалось быстрее при использовании в качестве катализатора триэтаноламина. Стоит отметить также, что триэтаноламин стоит дешевле, чем диазобициклоундецен, что объясняет его широкую распространенность в промышленном производстве.

Полученные экспериментальные данные могут быть использованы для оптимизации технологии нанесения полиуретановых защитных покрытий и позволят прогнозировать время полного связывания компонентов реакционной смеси для достижения оптимальных физико-механических показателей.

* Авторы благодарят руководство ЗАО НПХ ВМП в тиче вице-президента по научно-инновационной работе д. х. н. Д. Н. Кожевникова за предоставленные объекты исследования и проявленньй интерес к научно-исследовательской активности студентов ХТИ УрФУ. 


\section{Bibliography}

1. Wright P., Cumming A. Polyurethane elastomers. Per. from English. under the editorship of doctor. chem. Sciences N. P. Apukhtina. L., "Chemistry». 1973. 304 p.

2. Lipatov Yu. S., Kercha Yu. Yu., Sergeeva L. M. Structure and properties of polyurethane. "Naukova Dumka». Kiev, 1970. P. 37-52.

3. Melent'ev S. V., Malinovskaya T. D., Volokitin O. G. The Investigation of the polyurethane bindering composite fuel coating by the method of IR spectroscopy. The Collection of materials of the X International conference of students and young scientists «prospects of fundamental Sciences». Tomsk, 2013. P. 388-390.

4. Lipatova T. E., Bakalo L. A. Progress in the chemistry of polyurethanes. Kiev: Sciences. Dumka, 1972. P. 195-213.

5. Todosiichuk T. T., Kosyanchuk L. F., Antonenko O. I., Yashchenko L. N., Menieres G. Ya., Getmanchuk I. P., Gorbatenko A. N. Optimization of polyurethane curing opticallytransparent compositions. Journal of physical chemistry. 2012;2(20121):49-52.

6. Dechant I., Dance R. Infrared spectroscopy of polymers. M.: Chemistry. 1976. 459 p.

\section{Cite this article as (как цитировать эту статью):}

Korshunova N. A. Tukhvatullina R. F., El'tsov O. S. The study of the curing of the polyurethane coating by method of IR spectroscopy. Chimica Techno Acta. 2016;3(4): 268-277. 